Duguid, M. M., \& Thomas-Hunt, M. C. (2015). Condoning stereotyping? How awareness of stereotyping prevalence impacts expression of stereotypes. Journal of Applied Psychology, 100, 343-359.

Goff, P. A., Steele, C. M., \& Davies, P. G. (2008). The space between us: Stereotype threat and distance in interracial contexts. Journal of Personality and Social Psychology, 94, 91-107.

Goldstein, I. L. (1991). Training in work organizations. In M. D. Dunnette \& L. M. Hough (Eds.), Handbook of industrial and organizational psychology (Vol. 2, pp. 507-602). Palo Alto, CA: Consulting Psychologists Press.

Greenwald, A. G., McGhee, D. E., \& Schwartz, J. L. K. (1998). Measuring individual differences in implicit cognition: The implicit association test. Journal of Personality and Social Psychology, 74, $1464-1480$.

Hastorf, A. H., \& Cantril, H. (1954). They saw a game: A case study. The Journal of Abnormal and Social Psychology, 49, 129-134.

Holladay, C. L., Knight, J. L., Paige, D. L., \& Quiñones, M. A. (2003). The influence of framing on attitudes toward diversity training. Human Resource Development Quarterly, 14(3), 245-263.

Pettigrew, T. F., \& Trope, L. R. (2006). A meta-analytic test of intergroup contact theory. Journal of Personality and Social Psychology, 90, 751-783.

Richeson, J. A., \& Shelton, J. N. (2007). Negotiating interracial interactions: Costs, consequences, and possibilities. Current Directions in Psychological Science, 16, 316-320.

Ruggs, E. N., Hebl, M. R., Rabelo, V. C., Weaver, K. B., Kovacs, J., \& Kemp, A. S. (2016). Baltimore is burning: Can I-O psychologists help extinguish the flames? Industrial and Organizational Psychology: Perspectives on Science and Practice, 9(3), 525-547.

Sawyer, P. J., Major, B., Casad, B. J., Townsend, S. S. M., \& Mendes, W. B. (2012). Discrimination and the stress response: Psychological and physiological consequences of anticipating prejudice in interethnic interactions. American Journal of Public Health, 102, 1020-1026.

Shelton, J. N. (2003). Interpersonal concerns in social encounters between majority and minority group members. Group Processes and Intergroup Relations, 6, 171-185.

Sherif, M., \& Sherif, C. W. (1953). Groups in harmony and tension. New York, NY: Harper.

\title{
A Simple Solution to Policing Problems: Women!
}

Mindy E. Bergman, Jessica M. Walker, and Vanessa A. Jean

Texas A\&M University

Ruggs et al. (2016) describe paths through which industrial-organizational (I-O) psychology can make a dent in the ongoing policing problems in the United States. These paths include traditional I-O areas such as improved selection models, increased training, and changed organizational climates. However, there might be one fairly straightforward way in which police organizations can quickly reduce use-of-force problems: women. Because Title VII of the Civil Rights Act prevents selection based on sex, police departments obviously cannot hire women just because they are women. But po-

Mindy E. Bergman, Jessica M. Walker, and Vanessa A. Jean, Department of Psychology, Texas A\&M University.

Correspondence concerning this article should be addressed to Mindy E. Bergman, Department of Psychology, Texas A\&M University, 4235 TAMU, College Station, TX 77843-4235. E-mail: mindybergman@tamu.edu 
lice departments can and, we argue, should recruit more women to apply for police officer positions, create work practices and experiences that are attractive to and supportive of women (Hassell \& Brandl, 2009), and make efforts to retain female officers because of the evidence that female officers use less force when policing (Bolger, 2015). Additionally, police organizations and I-O psychologists should also work together to discover why women are less likely to use force and, subsequently, determine whether these characteristics can be selected or trained for in either sex. ${ }^{1}$

We aren't the first people to call for an increase in women in policing to reduce police brutality (Lonsway, Moore, Harrington, Smeal, \& Spillar, 2003; Spillar, 2015). The purpose of this commentary is to bring the I-O psychology perspective to bear on the role of women in policing and how we can leverage the evidence that women police are less likely to engage in extreme use of force than are male officers. In the following, we build the case for focusing on women -in terms of both increasing their representation in police organizations and using women as model officers on which competency modeling should be based-in police forces by (a) reviewing evidence demonstrating that female officers are less likely to use force, and more likely to use lower levels of force, than are male officers; (b) describing the sexbased demographics of police departments and why this matters practically; and (c) arguing that police organizations and I-O psychologists should invest in competency modeling that focuses on sex- and gender-based differences that correlate with use of force in order to create new selection and training models. First, however, we turn to the nature of force in policing in order to set the stage for the remainder of the commentary.

\section{Use of Force in Policing}

One of the hallmarks of policing is the ability to use force (Fyfe, 1988; Skolnick \& Fyfe, 1993). According to Payne (2012),

\footnotetext{
the potential for force colors every interaction police have with citizens. This is true for both police and the citizenry. A good deal of police training involves when and how to use force to resolve incidents. Citizens are acutely aware of the officer's training and authority during interactions with police. Uniformed officers carry the implements of force openly on their duty belts, after all. ... Police are the only institution in modern American society with a general grant of authority to use force to resolve disputes. Citizens call the police because the police can use force. (pp. 1,6)
}

The use of force is a hallmark of policing but becomes problematic when excessive force is used (Fyfe, 1988; Skolnick \& Fyfe, 1993). Excessive use of

1 Despite the use of "gender" in APA style to mean "biological sex," sex and gender actually mean different things. Sex refers to biological markers of male and female (and others, e.g., intersex persons), such as genetics and phenotypical body parts (e.g., genitals), whereas gender is the socially constructed expectations, behaviors, and experiences that are typically associated with a particular sex (Deaux, 1985; Unger, 1979). 
force is defined in fuzzy terms, usually as the use of more force than is necessary or reasonable (Skolnick \& Fyfe, 1993). This is why there are so many disagreements about whether particular police actions were appropriate as well as one of the reasons why there are many disappointments following investigations into police use of force. But it is also clear that some uses of force are excessive, such as in the cases that Ruggs et al. describe.

Throughout this commentary, we assume that an important criterion for police departments and the communities in which they serve is fewer fatal shootings of unarmed citizens. We do not suggest that this is the only important criterion in police work, nor do we suggest that police organizations should sacrifice quality on other performance criteria. However, as we will demonstrate next, women officers are less likely to use excessive force than are male officers, and thus police organizations should attempt to recruit and hire more women.

\section{Sex Differences in Use of Force}

Lonsway et al. (2002) summarized the literature on the use of excessive force and both civil liability cases (e.g., "police brutality" civil lawsuits) and citizen complaints about force in the United States. Their review clearly demonstrates that, compared with female officers, male officers (a) are significantly more likely to have the excessive force complaints against them sustained, (b) have significantly higher civil liability payouts, and (c) have a significantly higher rate of citizen complaints made against them. For example, at the Los Angeles Police Department in the 1990s, men made up approximately 80\% of the patrol force but $96 \%$ of payouts in excessive force cases; conversely, women composed approximately $20 \%$ of the patrol force and only $4 \%$ of payouts. As misconduct worsened, the disparity between male and female officers widened, such that there was a 23:1 general ratio in payouts, which increased to 32:1 when only assaults and battery were considered, which furthered increased to 43:1 when only killings by officers were considered (Spillar et al., 2000). These sex-based differences are seen across multiple indicators of excessive force for several large and midsized metropolitan police forces in the United States (Lonsway et al., 2002; Rabe-Hemp, 2008; see Porter \& Prenzler, in press, for similar results in Australia).

In addition to evidence that male officers are more likely to use extreme force than are women officers, the use of routine force appears to exhibit similar although much weaker sex differences. Bolger (2015) conducted a meta-analysis examining the situational, suspect, and officer characteristics that influence use-of-force decisions; Bolger found that there was a weak effect for male officers using force more than women officers did. This reflects the police use-of-force literature, which generally shows in individual studies that either (a) women officers are significantly less likely to use force than 
are male officers (Bazley, Lersch, \& Mieczkowski, 2007; Hoffman \& Hickey, 2005; Schuck \& Rabe-Hemp, 2007) or (b) female officers have lower rates of use of force than male officers, but the difference is not statistically significant (e.g., Paoline \& Terrill, 2005). Interestingly, there is evidence that situational and suspect characteristics associated with use of force differ across male and female officers (Paoline \& Terrill, 2005).

The effects of sex on use of force are enhanced when considering officer pairs (Schuck \& Rabe-Hemp, 2007). Schuck and Rabe-Hemp found that officer pairs consisting of two women were the least likely to use force and the most likely to use less extreme force, compared with other officer pairings. Further, within mixed-sex pairings, pairs in which the female officer had the bigger role in the encounter (e.g., was the arresting officer) used less force than did mixed-sex pairs in which the male officer had the larger role. Male-male pairs were the most likely to use force and the most likely to use more force, followed by male-led mixed-sex pairs.

In sum, these studies demonstrate that women officers are (a) less likely than are male officers to be implicated in cases of extreme force, (b) somewhat less likely to use routine force, and (c) less likely to use force when paired together or as leaders of a mixed-sex pair, compared with other pairings. Together, these studies suggest that more women officers would reduce the number of events that are at the extreme end of the use-of-force continuum.

\section{Police Demographics and the Subsequent Practical Effect on Use-of-Force Interactions}

Even small differences in use of force by male and female officers are amplified and take on practical importance when considered in light of the sex disparity within police forces in the United States and beyond (see Prenzler \& Sinclair, 2013, for a review of sex demographics in English-speaking police forces around the world). In 2015, of the approximately 688,000 police and sheriff's patrol officers ${ }^{2}$ who were employed in the United States, $13.6 \%$ were women $^{3}$ (Bureau of Labor Statistics, 2016). This ratio of male to female officers (6.35:1) has a staggering practical effect on policing behaviors within the communities they serve. Bolger (2015) found that male officers were 1.11 times more likely to use force than were female officers, indicating that for

2 Patrol officers are the uniformed police who patrol an area to ensure public safety and compliance with laws; they make traffic stops, arrest violators, attempt to prevent crime, and respond to calls from citizens; thus, patrol officers are of particular interest in the prevention of shootings of unarmed citizens.

3 At the same time, of the approximately 144,000 police detectives and criminal investigators, $27.2 \%$ were women; of the 110,000 first line supervisors of police and detectives, $12.8 \%$ were women. 
every 100 times female officers used force, male officers used force 111 times. But practically, given the ratio of male to female officers, this means that for every 100 times that one female officer used force, just over six male officers used force 111 times each or about 705 times in total. This means that the somewhat small elevation in use of force by male officers compared with female officers results in an extra 105 instances of force than would happen if male officers used force at the same rate that female officers do.

We can also estimate the reduction in the number of police contacts that use force if women accounted for $50 \%$ of patrol forces. Paoline and Terrill (2005) showed that women used force in $2 \%$ fewer of their contacts than did male officers ( $58 \%$ of contacts by male officers used coercive authority vs. $56 \%$ by female officers, nonsignificant). According to the U.S. Department of Justice, in 2008 there were nearly 67 million contacts between police and community members. Assuming that male and female officers ${ }^{4}$ engage with the public at a rate approximately equal to their proportion in the police force, approximately 9.1 million of these encounters were with female officers and 57.9 million were with male officers. Using Paoline and Terrill's (2005) descriptions of the rate of use of force by male and female officers, this means that of the 67 million contacts made by police in 2008, approximately 33.6 million were conducted by male officers and used force while 5.1 million were conducted by female officers and used force. However, if male and female officers each composed half of the police population at all ranks, male officers would use force approximately 19.4 million times per year, whereas female officers would use force approximately 18.8 million times per yearan overall reduction of 500,000 instances of use of force in a year's time from the current number of instances of force.

The above analyses account for use of force whether routine or excessive. However, male officers account for a disproportionately large share of excessive force complaints (Lonsway et al., 2002; Spillar et al., 2000). Thus, the effects of the above analysis regarding police demography would be even further amplified if only excessive force were considered.

\section{Job Analysis and Competency Modeling Focusing on Sex-Based Differences}

We have shown that women and men behave differently as police, at least in terms of use of force. Further, the causes of use of force appear to differ across male and female officers (Paoline \& Terrill, 2005). Beyond the policing literature, there is evidence that men are moderately more prone to both verbal and physical aggression than are women (Archer, 2004). The aggression literature shows that the gap between men's and women's use of aggression is

${ }^{4}$ For simplicity, we assume that police officers work solo, but in reality officers often work in pairs. 
reduced considerably when provocation is taken into account (Bettencourt \& Miller, 1996). Additionally, the aggression literature demonstrates that men and women differ in their perceptions of the cost of aggression to themselves and the target (Eagly \& Steffen, 1986).

Although these factors have been documented as sex differences, we do not believe that these are essentialist differences between men and women. Certainly, there are both biological and socialization factors that influence aggressive tendencies (see Hyde, 2014, for a review of theories of sex similarities and differences), both of which would be influential long before people enter the workforce. Of course, both women and men make good patrol officers who use force appropriately. But the sex differences that have been documented in police use of force and in aggression more broadly suggest that attending to how women police could provide insights into better models for selection and training that ultimately reduce shootings of unarmed citizens.

It is important to note that although women have assuredly been included in job analysis and competency modeling in police organizations to date, the demographics of police organizations suggest that job analyses and competency models for police officers are highly influenced by the perspectives and experiences of male officers. Even with careful attention to demographic representation in job analyses (and even oversampling of underrepresented groups), men's perspectives will overshadow women's. Not only are male officers more common in the patrol ranks than are women, but they are also more common among the leadership ranks; these leadersas subject matter experts-are likely to offer a gendered interpretation of effective policing, whether due to availability heuristics, confirmation bias, stereotypes, implicit biases, or just personal experience. This will cause job analysts to determine the frequency of and competencies for this (male) interpretation of effective policing. Further, there is ample evidence that women's comments are overlooked, suppressed, and dismissed in mixedgroup discussions when women are not a majority (or more) of the group membership (cf. Carli, 2013), which is problematic for the inclusion of women's perspectives if group discussions are used anywhere in the job analysis and competency modeling process. (These problems are further amplified when women who are also underrepresented minorities are considered.) Finally, police organizations on a whole are gendered as masculine, so that even notions of teamwork and communication outside of the contact with suspects are masculine, creating a culture of masculine expectations and a masculine organization beyond each individual's perspective (Acker, 1992).

Thus, we propose that it is important to examine how men and women police and where differences in policing behavior, perceptions, and attitudes 
lie. It is also important to create competency models of police work that are explicitly female and feminized (i.e., with women as the observed members, with women as the subject matter experts). Then applying these models to the selection of all recruits, regardless of sex, could result in lower use of force across all members of police organizations, which ultimately should result in fewer shootings of unarmed citizens and other forms of police brutality.

\section{Conclusion}

In this commentary, we demonstrated that, compared with female officers, male police officers are much more likely to use extreme levels of force and much more likely to be implicated in excessive force complaints and civil court cases. We also demonstrated that women officers are considerably fewer than are male officers, which means that small statistical differences regarding rates of use of force mushroom into large practical differences in number of use-of-force cases. Together, this evidence indicates that police forces - with the aid of I-O psychologists-should recruit, hire, and retain more women officers and create work environments in which women officers can thrive. It also suggests that researchers and practitioners should investigate sex-based factors related use of force to create stronger selection models that result in police organizations that keep citizens safe from both other civilians and from the police themselves.

\section{References}

Acker, J. (1992). From sex roles to gendered institutions. Contemporary Sociology, 21, 565-569. doi:165.91.74.118

Archer, J. (2004). Sex differences in aggression in real world settings: A meta-analytic review. Review of General Psychology, 8, 291-322.

Bazley, T. D., Lersch, K. M., \& Mieczkowski, T. (2007). Officer force versus suspect resistance: A gendered analysis of patrol officers in an urban police setting. Journal of Criminal Justice, 35, 183192. doi:10.1016/j.jcrimjus.2007.01.005

Bettencourt, B. A., \& Miller, N. (1996). Gender differences in aggression as a function of provocation: A meta-analysis. Psychological Bulletin, 119, 422-447.

Bolger, P. C. (2015). Just following orders: A meta-analysis of the correlates of American police office use of force decisions. American Journal of Criminal Justice, 40, 466-492. doi:10.1007/s12103014-9278-y

Bureau of Labor Statistics. (2016). Labor force statistics from the Current Population Survey. Washington, DC: Bureau of Labor Statistics, Department of Labor. Retrieved from www.bls.gov/cps/cpsaat11.htm

Carli, L. L. (2013). Gendered communication and social influence. In M. K. Ryan \& N. R. Branscombe (Eds.), The Sage handbook of gender and psychology (pp. 199-215). London, UK: Sage.

Deaux, K. (1985). Sex and gender. Annual Review of Psychology, 36, 49-81.

Eagly, A. H., \& Steffen, V. J. (1986). Gender and aggressive behavior: A meta-analytic review of the social psychological literature. Psychological Bulletin, 100, 309-330.

Fyfe, J. J. (1988). Police use of deadly force: Research and reform. Justice Quarterly, 5, 165-205. 
Hassell, K. D., \& Brandl, S. G. (2009). An examination of the workplace experiences of police patrol officers: The role of race, sex, and sexual orientation. Police Quarterly, 12, 408-430.

Hoffman, P. B., \& Hickey, E. R. (2005). Use of force by female police officers. Journal of Criminal Justice, 33, 145-151. doi:10.1016/j.jcrimjus.2004.12.006

Hyde, J. S. (2014). Gender similarities and differences. Annual Review of Psychology, 65, 373-398.

Lonsway, K., Moore, M., Harrington, P., Smeal, E., \& Spillar, K. (2003). Hiring and retaining more women: The advantages to law enforcement agencies. Arlington, VA: National Center for Women \& Policing. Retrieved from http://womenandpolicing.com/pdf/newadvantagesreport.pdf

Lonsway, K., Wood, M., Fickling, M., De Leon, A., Moore, M., Harrington, P., . . Spillar, K. (2002). Men, women, and police excessive force: A tale of two genders. A content analysis of civil liability cases, sustained allegations, \& citizen complaints. Arlington, VA: The National Center for Women \& Policing. Retrieved from http://www.womenandpolicing.org/PDF/2002_Excessive_Force. pdf

Paoline, E. A., \& Terrill, W. (2005). Women police officers and the use of coercion. Women \& Criminal Justice, 15, 97-119. doi:10.1300/J012v15n03_05

Payne, T. C. (2012). Research perspectives on the use and control of police force. Anchorage, AK: Anchorage Community Police Relations Task Force and University of Alaska-Anchorage Justice Center.

Porter, L. E., \& Prenzler, T. (in press). Police officer gender and excessive force complaints: An Australian study. Policing and Society: An International Journal of Research and Policy.

Prenzler, T., \& Sinclair, G. (2013). The status of women police officers: An international review. International Journal of Law, Crime, and Justice, 41, 115-131. doi:10.1016/j.ijlcj.2012.12.001

Rabe-Hemp, C. E. (2008). Female officers and the ethic of care: Does officer gender impact police behaviors? Journal of Criminal Justice, 36, 426-434.

Ruggs, E. N., Hebl, M. R., Rabelo, V. C., Weaver, K. B., Kovacs, J., \& Kemp, A. S. (2016). Baltimore is burning: Can I-O psychologists help extinguish the flames? Industrial and Organizational Psychology: Perspectives on Science and Practice, 9(3), 525-547.

Schuck, A. M., \& Rabe-Hemp, C. (2007). Women police: The use of force by and against female officers. Women \& Criminal Justice, 16, 91-117. doi:10.1300/J012v16n04_05

Skolnick, J. H., \& Fyfe, J. J. (1993). Above the law: Police and the excessive use of force. New York, NY: The Free Press.

Spillar, K. (2015, July 2). How more female police officers would help stop police brutality. The Washington Post. Retrieved on from https:/www.washingtonpost.com/posteverything/wp/2015/07/ 02/how-more-female-police-officers-would-help-stop-police-brutality/

Spillar, K., Harrington, P., Wood, M., Aguirre, P., Aguilar, S., Yick, J., . . . Meza, L. (2000). Gender differences in the cost of police brutality and misconduct: A content analysis of LAPD civil liability cases: 1990-1999. Arlington, VA: The Feminist Majority Foundation and The National Center for Women \& Policing. Retrieved from http://www.womenandpolicing.org/ExcessiveForce.asp? $\mathrm{id}=4516$

Unger, R. K. (1979). Toward a redefinition of sex and gender. American Psychologist, 34, 1085-1094. 